\title{
Empowering a fragmented diaspora: Turkish immigrant organizations' perceptions of and responses to Turkey's diaspora engagement policy
}

\section{Ayca Arkilic}

To cite this article: Ayca Arkilic (2020): Empowering a fragmented diaspora: Turkish immigrant organizations' perceptions of and responses to Turkey's diaspora engagement policy, Mediterranean Politics, DOI: 10.1080/13629395.2020.1822058

To link to this article: https://doi.org/10.1080/13629395.2020.1822058

\section{曲 Published online: 16 Nov 2020.}

Submit your article to this journal $₫$

Q View related articles $\widetilde{ }$

View Crossmark data $\nearrow$

Citing articles: 1 View citing articles ¿ 


\title{
Empowering a fragmented diaspora: Turkish immigrant organizations' perceptions of and responses to Turkey's diaspora engagement policy
}

\author{
Ayca Arkilic iD
}

Lecturer in Political Science and International Relations, Victoria University of Wellington, Wellington, New Zealand

\begin{abstract}
The existing literature on state-diaspora relations, primarily in the MENA, has mostly focused on how and why home states engage their diasporas, rather than with what consequences. This article investigates how different groups within the diaspora community are affected by the homeland's multi-tiered diaspora engagement policy. I argue that sending states influence select immigrant organizations' mobilization by empowering them in two key ways: They instil selfconfidence and collective identity in organization leaders and provide them with capacity-development and know-how support. Yet such differential treatment may become a source of suspicion in host states and cause resentment among the disregarded diaspora groups. The findings draw from extensive fieldwork conducted in France, Germany, and Turkey between 2013 and 2019 and original data derived from interviews, official documents, and news sources.
\end{abstract}

KEYWORDS Diaspora engagement; empowerment; immigrant organizations; Turkey; MENA; Europe

\section{Introduction}

Countries in the Middle East and North Africa (MENA) have a long history of emigration (Brand, 2018). The expanding scholarship on state-diaspora relations in the region has explored the relevance of human flows for citizenship; state authority, capacity, and strength; identity; and democracy (Moss, 2016; Pearlman, 2018) as well as for economic development and remittances (Iskander 2010; Fargues, 2013). Studies have also theorized the foreign policy importance of cross-border mobility in the MENA (Tsourapas, 2018a, 2018b) and authoritarian states' different exit, overseas, and return policies aimed at their émigré communities (Tsourapas, 2018c).

Another strand of the literature has looked at how and why governments have created institutions (amicales) and consular networks to deal with their emigrants (Brand, 2018). Moreover, some have paid attention to intradiasporic policies developed by MENA countries (Tsourapas, 2015; Arkilic, 
2016; Şahin-Mencütek \& Baser, 2018; Adamson, 2019; Yanaşmayan \& Kaşlı, 2019). However, as Aksel (2019) observes, the impact of diaspora engagement policies on home state-emigrant society relations and emigrants' transnational political practices remains understudied in the literature.

Turkey sends the largest number of emigrants to Europe. Guest worker programmes launched in the 1960s triggered large-scale Turkish emigration to Western Europe. Yet Turkey has institutionalized its diaspora engagement policy since the incumbent Justice and Development Party (Adalet ve Kalkınma Partisi, AKP) entered office in 2002. This article probes in detail how different groups within the Turkish expatriate community have viewed and been affected by the AKP's diaspora policy, which favours ideologically proximate and loyal groups that are seen as better able to serve its political interests.

My analysis shows that sending states affect select immigrant groups' mobilization $^{1}$ by empowering them in two key ways. First, policy-makers initiate a process of 'identity work,' which extols immigrants as hardworking, competent, and harmonious people who contribute to their home and host states. The homeland's positive and inclusive discourse restructures immigrants' previously marginalized identities and renders them more selfconfident. Sending states also instil feelings of collective identity by bringing immigrant organizations together for various activities and meetings, by drawing attention to their similarities, and by encouraging them to collaborate and form alliances with each other. The transformation of the image of certain immigrant organizations from one of stigmatization into one of normalization also helps organizations overcome past tensions and engage themselves in inter-organizational collaboration. By creating a common identity and purpose for the diaspora, sending states strengthen immigrants' group consciousness.

Sending states also empower immigrant organizations through the provision of capacity-development and know-how programmes. Such support creates a bridge for knowledge transfer between the homeland and organizations and rejuvenate the organizational capacity of immigrant organization leaders. The homeland's projection of collective identity combined with the provision of such support increase immigrant groups' visibility and clout in their host countries.

The article aims to contribute to the growing scholarship as the statediaspora relations literature, primarily in the MENA region, still tends to deal with how and why home states engage their diasporas, rather than with what consequences. Many researchers in this field have developed a state-centred perspective, which has discouraged them from collecting much-needed empirical data from individuals in the diaspora. In this regard, the fact that my extensive multi-sited fieldwork takes a different approach is a particular strength of the study. The findings of the article are relevant to other MENA countries 
that have developed bifurcated diaspora engagement policies and diasporas that have relocated to Western Europe in the postwar era, including but not limited to Moroccans in Belgium, France, Spain, Netherlands, and Italy; Algerians and Tunisians in France and Italy; and Egyptians in the UK, Italy, and Germany.

The article proceeds as follows. It first discusses case selection and methodology. It then provides a theoretical framework. The subsequent section looks at Turkey's shift from a passive to pro-active diaspora policy. Next the study examines Turkey's post-2003 outreach activities in France and Germany, and map their impact on conservative Turkish immigrant organizations. The final section details how Turkey's diaspora engagement policy has been received by other diaspora groups and European host states.

\section{Case selection and methodology}

Home to the largest population of Turkish citizens abroad, Europe is an ideal focus for this study. Approximately 5.5 million of the estimated 6.5 million Turkish citizens living abroad reside in Western Europe (Turkish Ministry of Foreign Affairs, 2020a). Data were collected during fieldwork in Turkey, France, and Germany. The first round was conducted in Ankara, Berlin, Cologne, Paris, and Strasbourg between January 2013 and February 2014. The second round was carried out in Paris and Berlin in January and February 2019 and in Ankara in June 2019. The selected cases France and Germany - host the highest number of Turks in Europe, with an estimated 650.000 in France and 3.4 million in Germany (Turkish Ministry of Foreign Affairs, 2020b, 2020c). Berlin, Cologne, Paris, and Strasbourg were chosen because the largest Turkish populations in France and Germany reside in these cities. Moreover, the headquarters of Turkish immigrant organizations and host states' governmental centres are located in these cities. Ankara was chosen as another key location since it is the diplomatic heart of Turkey.

France and Germany are suitable for comparison also because they have different citizenship models, church-state relations, and forms of government. By choosing two cases that present wide institutional variation, I can control for the explanatory power of host state-related factors, and therefore, illustrate the sending country effects more clearly. These two cases are also ideal for controlling for group-related and grievance-based factors because the Turkish immigrant organizations present in both countries display an overall resemblance. Even though the population of the Turkish community is significantly larger in Germany, the organizational characteristics of Turkish immigrant organizations in both countries are similar. Indeed, most organizations operate in both countries with the same names and transnational networks link immigrant organizations operating in France closely to those in Germany (Schiffauer, 2010). 
The primary findings draw on 39 semi-structured, in-depth elite interviews. I spoke with the chairs, spokespersons, and board members of prominent Turkish immigrant organizations in France and Germany. These include, but are not limited to conservative organizations, such as the Turkish-Islamic Union for Religious Affairs (DiTiB), the Milî Görüş, the Turkish-Islamic Union in Europe, the Union of Islamic Cultural Centres (Süleymancılar), the Turkish Federation, and the Council for Justice, Equality, and Peace (COJEP). I conducted interviews with representatives of other organizations as well, such as the Turkish Community in Germany (TGD), the Assembly of Citizens Originating from Turkey (ACORT), the Federation of Alevi Unions in Germany (AABF), and the Federation of Alevi Unions in France (FUAF). All of my interlocutors greeted me positively. Regardless of their ideological position, they were happy to see a rare scholarly interest in their views, and hence, provided a detailed account of their experiences. I rely on secondary literature and journalists' interviews to examine how Kurdish and Gülenist ${ }^{2}$ groups interpret Turkey's increasing sway over the Turkish diaspora in Europe.

Interviews were also conducted with Turkish policy-makers from various institutions. These include the newly-established Directorate for Turks Abroad and Related Communities (YTB), which coordinates official activities targeting overseas Turks; the Ministry of Foreign Affairs; the Directorate of Religious Affairs (Diyanet); Turkish diplomatic missions; and the Union of International Democrats (UID), ${ }^{3}$ which streamlines the Turkish diaspora's political lobbying activities. The archival research covered the YTB's activity reports and official statements by policy-makers. In addition, I surveyed various news sources in English, French, German, and Turkish.

This study's analytical focus is on immigrant organizations. Glick-Schiller (2013) warns scholars about the 'ethnic association fetish.' In her view, an excessive focus placed on immigrant organizations presents a limited portrayal of transnational immigrant behaviour given that diaspora organizations represent a small portion of the diaspora community. However, I choose to focus on immigrant organizations for two reasons. As the de facto representatives of immigrants in Europe, immigrant organizations constitute the most important claims-making actors and co-constructors of political debates pertinent to immigration and integration, and serve as a bridge between their home states and local immigrant communities (Schrover \& Vermeulen, 2005). Moreover, since 9/11, Turkish immigrant organizations have become increasingly important actors in Europe (Rosenow-Williams, 2012; Arkilic, 2015).

\section{Shifting scholarly attention to origin states}

Immigrants' collective mobilization has been explored from multiple theoretical perspectives. The first account focuses on the specific characteristics of immigrant groups, such as a common class-consciousness (Castles \& 
Kosack, 1973); social capital, group size, or leadership strategies (Fennema \& Tillie, 1999; Ganz, 2000); and length of stay in the host country (Mügge, 2012). Other scholars emphasize cultural, religious, or political characteristics. Ögelman (2000), for example, has argued that cultural differences explain different forms and rates of mobilization among Turkish, Italian, and (former) Yugoslavian immigrants in Germany.

Yet the literature on immigrants' group-related characteristics leaves a great deal of space for additional research. The relevance of common class identity has decreased over time (Koopmans et al., 2005). In addition, this approach cannot account for the fact that Muslim immigrants from different sending states do not always participate in politics at similar rates (Maxwell, 2012). More importantly, even different immigrant groups from the same country may engage in collective political action at very different rates. Studies have also shown that large numbers do not guarantee successful political mobilization (Schönwalder, 2013). Finally, while immigrants' strategic leadership can play a key role in their successful mobilization, the ways in which the homeland's diaspora engagement policy shapes leadership needs to be explored further in this literature.

Another approach claims that the institutional opportunities and constraints within host states determine immigrant groups' political activities (Koopmans et al., 2005). Ireland (1994), for example, has shown that foreign workers in similar industrial sectors in different host countries follow divergent participatory trajectories. Others have agreed that different models of integration and citizenship give rise to various sets of opportunities for immigrants to participate in the political sphere (Cinalli \& Giugni, 2013).

This approach has several limitations too. First, most studies examining the effects of citizenship policies generate mixed findings (Bevelander \& Veenman, 2006). This literature also portrays immigrants as passive receivers of institutional policies, which flies in the face of reality. Institutional typologies related to host states have not been able to explain differences among immigrant groups within the same country or similarities among immigrant groups across countries either (Maxwell, 2012; Strijbis, 2015). The surrounding political context mediates the way that immigrant organizations perceive and respond to home state policies. For example, Vermeulen (2018) has shown that the political environment in European host countries has changed immensely and negatively for Turkish expatriates since 9/11 due to the rise of Islamophobia and far-right political parties. Therefore, this approach should be combined with homeland-induced factors that may also play a significant role in immigrants' collective political action.

A third approach suggests that immigrants' collective perceptions of their status in their host country's ethno-racial context determine the degree of immigrant political mobilization (Yalaz, 2014). This body of literature 
distinguishes between 'group consciousness,' which denotes 'in-group identification politicized by a set of ideological beliefs about one's group's social standing,' and 'group identification,' which refers to 'a psychological sense of belonging or attachment to a social group' (McClain et al., 2009). These scholars argue that while group identification does not always trigger political mobilization, group consciousness is a necessary condition for it to occur.

While this perspective has its merits, it cannot clarify the timing of political mobilization because the level of grievances usually remains high and constant among subaltern groups (Goodwin, 2001). Turkish Muslims in Europe have long felt disadvantaged or discriminated against (Kaya, 2019), yet have become increasingly politically active only recently (Yalaz, 2014). Since Turks' grievances date back to the 1960s and are chronic in both countries, some other factor must be at play in activating collective political action.

A common weakness of the above-mentioned approaches is that they do not pay sufficient attention to sending states. The literature on transnationalism has shifted the scholarly focus to them by suggesting that political identity and activities are shaped by both home and host state factors (Østergaard-Nielsen, 2003b; Morales \& Morariu, 2011). However, these studies are mainly concerned with how origin states respond to the transnational activities of immigrants or how immigrants' political activities towards their countries of origin affect immigrant integration. In a similar vein, the literature on state-diaspora relations has noted that the orientation of sending states towards immigrants is as important as host states' relations with their immigrants. Some studies have categorized origin countries' policies aimed at their diasporas and addressed how and why states form diaspora policies to cultivate closer ties with them (Varadarajan, 2010; Gamlen, 2018). Yet, despite their contributions, these accounts do not sufficiently identify the ways in which sending states' diaspora policies influence diaspora groups. While a few recent studies have speculated that origin states' increasing engagement with their diaspora communities might affect immigrants' political integration in host countries (Gsir, 2014), they have not explained the mechanism by which the origin state's engagement with the diaspora directly influences immigrants' mobilization in host states.

\section{From a passive to pro-active diaspora engagement policy}

The ways in which Turkish policy-makers approach the Turkish diaspora in Europe have changed dramatically over time. In the 1960s and 1970s, Turkish bureaucrats tended to view Turkish emigrants as uneducated 'remittance machines.' Since guest workers were believed to return to Turkey after the termination of their short-term contracts, Turkey's main motivation at that time was to use them as a safety valve against unemployment and to promote remittance inflows (Aksel, 2019). 
In the 1980s and 1990s, Ankara became more interested in containing dissident immigrant activities. In the 1970s, the clash between the right- and left-wing groups served as the main dividing line in Turkish politics. In the 1980s, a plethora of other cleavages between seculars and conservatives, Turkish and Kurdish nationalists, and Sunnis and Alevis became visible (Ögelman, 2003). The 1980 military coup that ended the conflict between the right- and left-wing factions did not bring peace to the country as it was followed by the ongoing civil war between Turkey and Kurds and suppression of Alevis. The military government that stayed in power between 1980 and 1983 labelled diaspora organizations as 'allies' and 'enemies.' Secular organizations were in the first category as they imported the Turkish state's secularist-nationalist discourse to the transnational space. Alevi, Kurdish, and leftist groups, on the other hand, were seen as suspicious groups threatening the unity of the state (Şenay, 2013). The government also distinguished between state-controlled Islam, represented by the Diyanet and its DiTiB, and other Islamic organizations (Akgönül, 2005). In parallel to the worsening political situation in the 1980s and 1990s, asylum appeals to European countries reached record numbers (Sökefeld, 2008). Emigration of ethnic and religious minorities and political dissidents at increasing rates created a very heterogeneous Turkish diaspora.

A more institutionalized diaspora engagement policy came into existence with the AKP's rise to power in 2002. In 2003 a parliamentary commission was set up to address Euro-Turks' socioeconomic, political, and religious problems. This was a turning point for the AKP's new diaspora policy. An official from the YTB argued that the development of a pro-active diaspora agenda under the AKP is closely linked to the AKP government's strong political will and Turkey's growing economic and political power in the region. ${ }^{4}$

During its second term between 2007 and 2011, the AKP's initial commitment to bringing the country closer to the EU led the party to pass significant constitutional and judicial reforms and to introduce the Alevi and Kurdish Openings as the first comprehensive official initiatives aimed at responding to Alevis' and Kurds' identity-based demands (Arkilic \& Gurcan, 2020). While the effects of the AKP on the formerly stigmatized Islamist groups, such as the Gülen Movement and the Millî Görüş were visible from the early days of the AKP's rise to power (Akgönül, 2019), the party empowered them even further over time by creating a 'more vibrant civil society in which religious expression and religious organizations became more prominent' (Adamson, 2019, p. 224). Targeted by the old secular establishment, the AKP and the Gülen Movement's mutually beneficial relationship was particularly strong, 'with the former's political office reinforcing the latter's social and bureaucratic power and vice versa' (Taş, 2017, p. 395). The AKP elite's rapprochement with these groups influenced the Turkish transnational space significantly (Bruce, 2019). 
Over the last decade, the AKP has succumbed to competitive authoritarianism (Esen \& Gumuscu, 2015) and a process of de-Europeanization (Aydın-Düzgit \& Kaliber, 2016, p. 6). The AKP's relations with secular, Alevi, and Kurdish diaspora groups have soured particularly after the 2013 Gezi Park protests and the collapse of the Alevi and Kurdish Openings. The AKP's partnership with the Gülen Movement also started to dissolve in 2010 with the demise of their common enemy. Their disagreement became publicly visible in 2013 and turned into a brutal fight in 2016 that resulted in the failed coup attempt (Taş, 2017).

A sizable body of the literature (Østergaard-Nielsen, 2003a; Ünver, 2013; Aydın, 2014; Öktem, 2014; Okyay, 2015; Arkilic, 2016, Forthcoming) has shown that while Turkey's earlier policies were ad hoc and aimed at attracting remittances, lobbying for Turkey's EU membership, and controlling subversive Islamist and Kurdish political dissidence, the AKP's policies are driven by new incentives. These include promoting a positive image of Turkey, extending the state's legitimacy and 'soft power' beyond borders, and garnering diaspora votes. The AKP also seeks to recruit the Turkish émigré community as a lobby group against host-state policies and developments that are deemed inimical to Turkey's interests. Recognition of the mass killings of Armenians by Ottoman Turks in 1915 as genocide, support for the Kurdish and Gülenist diaspora groups, and the rise of Islamophobia are salient examples.

\section{The Turkish state's diaspora engagement activities in France and Germany in the post-2003 era}

\section{Mass diaspora rallies}

Mass rallies organized abroad constitute an essential component of the Turkish state's diaspora empowerment policy. For example, at a first-of-itskind rally held in Paris in 2010, Turkey's then Prime Minister and AKP leader Recep Tayyip Erdoğan urged overseas Turks to participate in French politics:

\footnotetext{
Please know that you are not alone here. Your happiness is our happiness. Your sorrow is our sorrow (...) Pursue your legal rights in France. Why don't we see our Ahmet, Mehmet, Hasan, Ayşe, Fatma in the French or European Parliaments? You must take this step. If you don't take advantage of this [opportunity], others will. Unite, act together, fight together, be strong, be assertive (...) If you take these steps, you will contribute immensely to your country [Turkey] (CNN Türk, 2010).
}

At some of his rallies, such as the 2014 Lyon rally, Erdoğan praised diaspora Turks and urged them to advance Turkish interests abroad by lobbying the French government to change its 'Armenian policy' (Hürriyet, 2014c). Such rallies also condemn supporters of the Kurdish and Gülenist movement and 
serve as platforms to promote the AKP's policies and achievements among diaspora voters.

A similar identity-engineering process through rallies is underway in Germany. At a rally attended by 20,000 in Cologne in 2008, German-Turks gathered for the first time to hear Erdoğan speak: 'The Turkish people are people of friendship and tolerance. Wherever they go, they bring only love and joy (...) Turkey is proud of you!' (Der Spiegel, 2008). Three years later, in Düsseldorf, 10,000 Turks gathered to hear Erdoğan warn against assimilation:

They call you guest workers, foreigners, German-Turks. It doesn't matter what they call you. You are my fellow citizens, you are my people, and you are my friends (...) You are part of Germany, but you are also part of our great Turkey (...) Integrate into German society, but do not assimilate (...) Assimilation is a crime against humanity (Der Spiegel, 2011).

Most rally-goers are followers of conservative Turkish immigrant organizations (Deutsche Welle, 2008). Some of my respondents noted that these organizations are key drivers of attendance at such rallies, chartering buses and providing free meals. ${ }^{5}$ When asked by journalists to explain his appeal, rally participants typically report that Erdoğan is a source of pride for them. For example, one 2011 Düsseldorf rally-goer affirmed Erdoğan's image as a champion of diaspora Turks' welfare: 'Germany will never accept us, but we have Erdoğan.' 'At last someone feels responsible for us; for the first time a Turkish Prime Minister [President] isn't forgetting his compatriots abroad,' added another (Der Spiegel, 2011). While the bulk of rally attendants are great admirers of Erdoğan, at almost every rally several hundreds of opponents mobilize to protest him (Deutsche Welle, 2018b).

\section{The outreach activities of the YTB}

The YTB has been providing generous financial assistance to civil society organizations operating abroad. Between 2011 and 2020, the YTB has provided USD 17 billion to support over 1000 civil society projects in 70 countries (YTB, 2020). Turkey has empowered select diaspora organizations in France and Germany through generous YTB funding as well. For example, sixty per cent of the total amount of financial aid provided to Turkish immigrant organizations in France was earmarked for lobbying, educational, and capacity-development activities. The YTB provides this funding so as to enable organizations to 'conduct more effective and professional activities [and] make significant contributions to "societal development," "public opinion," and "active citizenship" in France.' In a similar vein, eighty-seven per cent of the corresponding YTB funding for German-Turkish immigrant organizations supported lobbying, educational, and capacity-development activities (YTB, 2015a, pp. 56-57). My 
interviews with representatives of Turkish immigrant organizations in both countries revealed that conservative organizations have received the lion's share of YTB support since the institution was established in 2010.

The YTB promotes active citizenship through other programmes as well. Its Civil Society Workshops are a flagship activity. As an official from the YTB reported, these workshops are designed to empower Turkish immigrant leaders by boosting their ability to actively participate in the economic and political life of the host country. ${ }^{6}$ The Election Information Campaign launched in France and Germany also fosters civic engagement among Turkish immigrant leaders. This campaign aims to inform Turks of their electoral rights in their home and host countries (YTB, 2015a, p. 41, 2015b, pp. 39, 70).

The YTB has also convened training programme in France and Germany. For example, 41 civil society leaders participated in a programme held in Strasbourg in 2014 that covered how to submit project grant applications to French and European authorities. More than 40 Turkish immigrant organization representatives participated in a similar meeting in Berlin in 2015. The same year, the UID organized a larger gathering for diaspora leaders in Istanbul. The event included seminars led by 60 UID officials who shared crucial capacity-building and empowerment strategies (YTB, 2015b). In February 2016, the YTB convened other events in Berlin, Gelsenkirchen, Hamburg, Hannover, Cologne, Mannheim, and Munich. In March 2016, a workshop focusing on the development and empowerment of Turkish diaspora media outlets was held in Frankfurt (YTB, 2016).

Active citizenship is also facilitated through the International Justice Programme and the Anti-Discrimination Project. The former took place in both France and Germany in 2012 and aims to educate Turkish citizens living abroad about their legal rights (YTB, 2015a). The latter was established to help Turkish organizations in Europe combat racism and discrimination. This complements the Active Citizenship and Equal Participation Programme reserved for Turkish immigrant organizations (YTB, 2015a).

In addition, the YTB strives to improve organizations' lobbying capacity concerning the Armenian issue. In 2015, it published A Centennial Issue: New Approaches in the Democratization Process (1915-2015). The book's aim was to 'enlighten Turkish and European society regarding the Armenian issue in the most accurate manner' (YTB, 2015a, p. 50). Translated into several languages, the book has been distributed to universities, public libraries, and civil society organizations.

\section{Empowering select conservative Turkish diaspora leaders in France and Germany}

While Turkish-run conservative organizations have been operating in France since the 1960s, in the past, their political actions were sporadic and 
dispersed. Yet, as my interviewees have noted, this has changed radically since 2003. Turkey's diaspora engagement policies have alleviated French Turks' collective action problems by rendering them more self-confident and organizationally capable.

The Turkish Consulate in Paris has asked the representatives of the leading Turkish-Islamic organizations in France to create a joint platform to discuss common problems and to promote collective interests. As a Turkish diplomat noted, this request stemmed from the AKP government's new understanding of the role of Turkish immigrants in Europe. ${ }^{7}$ Another official from the Turkish Consulate in Paris pointed out that both political developments in Europe, such as rising Islamophobia and Turkey's diaspora engagement efforts have influenced the Turkish diaspora's recent mobilization efforts. ${ }^{8}$

France's uncompromising opposition to Turkey's EU membership triggered the first large-scale political mobilization among several conservative Turkish umbrella organizations in 2008 (Yalaz, 2014). As a DiTiB official explained, this event prompted a sharp rise in the number of Turkish people running for office in France. ${ }^{9}$ In the 2008 elections, 200 Turkish-origin French citizens ran in municipal assembly and vice-mayoral races. Of these, 107 were elected as councillors. With only four Turks having been elected to local councils in the 2001 elections, this was an unexpected political development (Hürriyet, 2014b). Today there are approximately 200 Turkish-origin councillors in France, an increase encouraged by Ankara. ${ }^{10}$

Another ground-breaking development that led to significant collective action from conservative Turkish organizations occurred in 2011 when the French Senate passed a bill criminalizing denial of the 1915 mass killings of Armenians by Ottoman Turks as a genocide (Le Monde, 2012). Leaders of conservative organizations, including the DiTiB, the Millî Görüş, the Turkish Federation, the COJEP, and the Union of Islamic Cultural Centres, formed a coordination council to organize rallies across France against the proposed bill. In 2012, this council organized the largest ever collective demonstration of Turks in France: 35,000 people gathered in Paris with banners reading 'No to the Shame Law.' As one of the event's organizers reported to me, such political commitment and cooperation among Turkish-Muslim organizations was previously unheard-of and this rally was organized thanks to the Turkish state's endeavours to stymie the influence of Armenian lobby groups in France. $^{11}$

In 2012, the DiTiB, the Millî Görüş, and the COJEP organized another mass political campaign - this time to mobilize the Turkish population for the national and local elections in France. The 'Now or Never' campaign started in Strasbourg and quickly spread to 35 French cities. These organizations cosponsored a video inviting French Turks to turn out to vote and even to run for office. This campaign evolved into a larger electoral campaign for the 2014 local elections. Other electoral campaigns, including 'Do Something Now' and 
the 'Time is Up!,' have also been organized to encourage French Turks' participation in local politics. A COJEP representative, who had organized one of these campaigns said:

We feel more self-confident recently (...) Turkish officials (...) encourage us to apply for dual citizenship, participate in French politics, and preserve Turkish culture and values. Not long ago, Turkish politicians ignored us completely. This attitude has changed with the AKP. New institutions, such as the YTB, provide us with both moral and financial support. This opens space for joint action. ${ }^{12}$

The DiTiB, the Millî Görüş, the UID, the COJEP, and the Turkish Federation came together on other occasions as well. In November 2018, their joint press release urged the French government to denounce the genocide law, and condemned the Coordination Council of Armenian Associations, which calls for the recognition of the mass killings as genocide. ${ }^{13}$ As a representative from the Turkish Federation asserted, Turkish immigrant organizations will soon create an overarching commission to expedite the Turkish diaspora's lobbying efforts with respect to the Armenian issue. ${ }^{14}$

These organizations collaborated once again in the same year to protest the Paris municipality's decision to allow a march organized by Kurdish separatists and to support the Turkish state in its fight against Kurdish terrorism in Afrin, Syria. ${ }^{15}$ Some conservative Turkish organizations also protested certain municipalities in Paris for endorsing Kurdish (Artı33, 2018) and Gülenist groups (Sabah, 2018).

A DiTiB official in France noted that the diaspora policy shift has directly affected their political engagement: 'It feels good to have Turkey backing us (...) Our people are no longer reluctant to obtain French citizenship. Erdoğan's words encourage us. ${ }^{16}$ Another DітіВ leader agreed:

Before the 2000s, Turks were an introverted and fragmented community (...) Turkey's growing strength has empowered us. Even the way French policymakers look at us has changed recently. We [Turks in France] owe this to the AKP government (...) Now Turkish officials get together with civil society leaders. They tell us: "You are not alone." Our government looks after us. In turn, our position here has strengthened (...) Fifteen years ago we were antagonistic towards each other. Today we [conservative diaspora groups] work together. ${ }^{17}$

According to a third DiTiB official:

Turks in France are representatives of Turkey. If Turkey invests in our capacity and skills, both sides win (...) The YTB was established with this goal in mind. It aims to boost our resources and gives us direction. It teaches us how to write projects, how to prepare press speeches, how to engage French politicians, and how to take action together despite our differences. ${ }^{18}$

A Millî Görüş board member in Paris insists that the homeland's policies have boosted collective Turkish-Muslim pride in France: 'We lean upon Turkey; we are no longer alone.' This leader is also satisfied with the capacity-building 
activities designed for them: 'In diaspora meetings and capacity-development seminars, we discuss how we can reinforce our position in Europe. ${ }^{19}$ Another official added that YTB officials urge Turkish-Muslim organizations to form joint political platforms so that they can speak with one voice while defending Turkish interests in France. $^{20}$

Other Millî Görüş officials confirmed that conservative organizations no longer see each other as enemies, but rather as allies. For example, the DітіB now sends imams to the Milî Görüş for a period of two years, which is a new development blurring the boundaries between the Millî Görüş and the DiTiB. The Millî Görüş has also floated project partnerships with the YTB and established an umbrella organization with the DiTiB and the Turkish Federation in Strasbourg and Metz. ${ }^{21}$ The Millî Görüş's partnership with the AKP became evident once again with the election of Mustafa Yeneroğlu, the Milî Görüş's former chairman in Europe, as an AKP MP in 2015. However, Yeneroğlu's resignation in 2019 signals that the Millî Görüş remains a separate entity despite its rapprochement with the DiTiB.

Union of Islamic Cultural Centres representatives in France have also discussed partnership opportunities with the YTB and met with other conservative Turkish organizations to organize joint activities, such as Holy Birth Week celebrations commemorating the birth of Prophet Mohammad. Once unthinkable, they stress the 'common consciousness and synergy' created by Turkish diaspora organizations in France as a positive development. ${ }^{22}$

As in France, the collective political action of Turkish-Muslim leaders in Germany has grown spectacularly over the last decade under Ankara's guidance. For example, while conservative Turkish organizations paid scant attention to the late 1990s citizenship debate, they began to voice political claims regarding dual citizenship only after 2010 (Yalaz, 2014). As two officials from the Turkish Embassy ${ }^{23}$ and Consulate ${ }^{24}$ in Berlin explained to me, before 2003, Turkish diplomats remained at arm's distance from Islamic organizations as they were seen as a threat to the secular state. This is no longer the case. Another Turkish official also indicated that, in the post-2003 era, once frosty relations between the Turkish government and conservative immigrant organizations in Europe have blossomed due to the Diyanet's willingness to send imams to different Islamic organizations. ${ }^{25}$

In 2012, several organizations, including the DiTiB and the Millî Görüş, led a signature campaign asking the federal government to grant Turks dual citizenship. Using the slogan 'Dual Citizenship for Everyone,' they managed to collect 40,000 signatures in Berlin, which were later submitted to German party leaders (Hürriyet, 2012b). Another signature campaign titled 'Do Not Meddle with Our Language!' launched in August 2012, lobbied for optional Turkish language instruction in public schools (Hürriyet, 2012a).

The largest collective political action led by conservative Turkish organizations in Germany came right before the September 2013 federal elections. 
The Millî Görüş, the DiTiB, and the Union of Islamic Cultural Centres led a nation-wide political campaign titled 'Go to the Ballot Box!' - the first major effort ever by Turkish-Islamic organizations to boost electoral participation among Turks in Germany (Yalaz, 2014).

Seeking further recognition, in 2014, the DiTiB initiated the 'Muslim Community Registry' campaign to count and register members of the Turkish-Muslim community in Germany (Hürriyet, 2014d). To achieve the status of a corporation under public law (Körperschaft des öffentlichen Rechts), which extends certain subsidies and privileges to Evangelical, Catholic, and Jewish communities, Islamic immigrant organizations must reach a high threshold of followers. The Muslim Registry Campaign's main goal was thus to prove that the Turkish-Muslim population in Germany is sufficiently large.

Anti-discrimination is another new action area for conservative Turkish organizations in Germany. In 2014, Turkish-Islamic organizations delivered a joint press release that took a strong stand against the Pegida movement (Pitt, 2014). Following the press release, they staged a joint demonstration in Cologne to condemn racism and hatred against Muslims (Hürriyet, 2014a). Four years later, officials from major Turkish-Islamic organizations met with German President Frank-Walter Steinmeier to express their concern about rising hate crimes and mosque attacks in Germany (Anadolu Ajansı, 2018).

In 2015, DiTiB, Millî Görüş, and Union of Islamic Cultural Centres representatives also held a joint press conference criticizing the recent German parliamentary motion that labelled the 1915 mass killings of Ottoman Armenians as genocide (BBC, 2015). This was followed by joint action - the 'Peace and Friendship March against Genocide Allegations' demonstration - in Cologne (Hürriyet, 2015). A similar demonstration took place a year later (Sabah, 2016).

A DітіB leader in Germany commended this unprecedented rapprochement among conservative organizations as a promising development. ${ }^{26}$ Other DітіB representatives in Germany noted that this recent collective mobilization is a reflection of the homeland's support. According to a DітіB official in Berlin, 'economic and political changes in Turkey have had tremendous repercussions for us. Finally, we can proudly declare that we are Turkish. Our self-esteem has increased. ${ }^{27}$ Another official emphasized that:

Erdoğan's rally messages are very supportive and constructive. They unite us. In the past, we used to bow our heads. We were weak. His messages give us power (...) His firm stance (...) gave us group consciousness (...) Another important development is the YTB's support. They help us draft project proposals so we are more successful with funding applications. ${ }^{28}$

Millî Görüş leaders in Germany also feel newly empowered. An official from the Berlin branch underscored the confidence-boosting effect of Turkish diaspora policies: 
Developments in Turkey directly influence the organizational landscape here (...) We receive both moral and financial assistance [from Turkey] (...) We are no longer alone (...) Our activities and projects are now far more geared toward political participation and collective action. For example, we organized an extensive election campaign with other Turkish organizations, including the DiTiB and the Union of Islamic Cultural Centres, for the 2013 German federal elections. We showed local authorities that we are a powerful group. ${ }^{29}$

Millî Görüş officials also attributed conservative organizations' recent reconciliation and empowerment process to the efforts of the AKP government: '[I]n the past, even if we wanted to work together with other organizations, this was not possible (...) The AKP doesn't take sides. It says: "We support brotherhood." They promote our cooperation. ${ }^{30}$ Another representative from the organization praised the YTB's support to their activities and projects and added that 'when Reis (Chief) Erdoğan visits us in Berlin, we feel very happy, protected, and motivated, especially against the backdrop of the rise of racism and Islamophobia in Europe.' He also argued that conservative Turkish organizations' rapprochement has been taking place only recently, which coincides with the AKP's rise to power and its inclusive attitude towards conservative immigrant organizations. One such example of interorganizational cooperation in Germany are personnel exchanges among the DiTiB, the Millî Görüş, and the Turkish Federation. ${ }^{31}$

Like their counterparts in France, Union of Islamic Cultural Centres representatives in Germany concurred with other conservative organization leaders that Turkey's new diaspora policy has paved the way for heightened collaboration among Turkish-Muslim organizations and improved their capacity to mobilize jointly. As a leader from the Berlin branch recalled, 'before the 2000s, Turkish-Muslim leaders from different organizations did not even say hi to each other. Now we co-organize iftar dinners during the Ramadan month. We campaign together. We lobby together. ${ }^{32}$ 'We no longer feel vulnerable,' concluded another official. ${ }^{33}$

\section{Resentment in a divided diaspora and growing tension with host countries}

Most conservative Turkish representatives in France and Germany feel empowered by Turkey's new diaspora agenda. However, others report that relations with the Turkish government have deteriorated amidst the rise of political Islam in Turkey and the development of a biased diaspora engagement policy. My interviews reveal how much more excluded by the Turkish government some organization leaders have felt in the post-2003 era.

While the Sunni-Alevi rift is a cleavage of long standing, FUAF representatives suggested that the divide has deepened under AKP rule and that Alevis feel more suppressed now than before. Other Alevi leaders argued that 
Turkey's new diaspora institutions discriminate against them, favouring instead Sunni organizations. ${ }^{34}$ A Paris Alevi Cultural Centre representative claimed his organization receives no financial support for its projects from the YTB and that no Alevi representative from France serves on the YTB's advisory board. ${ }^{35}$ This official cites the lack of Alevi representation on YTB committee and in various meetings as evidence that Turkey's new diaspora policy generally overlooks Alevis. Other FUAF representatives decline to participate in YTB meetings and diaspora rallies because they 'oppose the AKP's Sunnification agenda in the diaspora. ${ }^{36}$ These leaders maintained that as Alevi leaders have felt increasingly excluded by their origin country, they have established closer relations with French authorities.

Alevi representatives in Germany complained that the current diaspora policy actually undermines Turks' integration. One AABF official asserted that 'diaspora mobilization should be bottom-up rather than top-down. We must create and mobilize our own diaspora. ${ }^{37}$ Another AABF representative stated that the AKP government ignores the needs of the Alevi and Kurdish communities, declaring that these groups receive no financial or moral support from the government. They noted that being excluded lets them distance themselves from the 'brutal and assimilationist Turkish state' and approach German authorities that view them as 'good immigrants. ${ }^{\text {. }}$ '

Officials from secular organizations, such as the ACORT in France, suggested that the rise of Sunni-Muslim nationalism in Turkey has affected them negatively. ${ }^{39}$ These officials stress the selectivity in Turkey's diaspora agenda:

In the early 2000s, we backed a political campaign to promote Turkey's EU membership. We met with the Turkish Ambassador and Consul-General in Paris but were blocked. Instead, they backed a different organization with a campaign controlled by Turkish officials. Turkey does not support ideologically non-conformist organizations like ours. Yes, the Turkish government has provided resources to empower Turkish immigrant organizations here - but only like-minded ones. We receive no financial or organizational support for our activities. ${ }^{40}$

Officials from the secular TGD in Germany agreed that the Turkish diaspora's fragmentation has intensified in recent years. ${ }^{41}$ Another representative from the same organization criticized Turkey's diaspora agenda for its religious and nationalistic focus and highlighted that state agencies have distanced themselves from non-religious organizations even more under AKP rule:

Things have changed in recent years. Before the 2000s, Turkish ministers would stop by our office when visiting Germany. Now Turkish bureaucrats ignore us. We are invited to official meetings in Ankara. However, we feel as if we are a minority in these meetings. Religious organizations outnumber us (...) Our relations with the government have worsened since the Gezi Park protests. At a press conference, we condemned human rights violations committed by the AKP during those events. A Turkish MP then cancelled a scheduled visit with us. The UID also suspended ties once it saw our political stance. ${ }^{42}$ 
Kurdish representatives also conclude that the Kurdish diaspora in Europe perceives itself as more stigmatized under the new policy. They note that Turkey's approach has done more harm than good, damaging Turkey's image in Europe and undercutting integration efforts in France. The AKP's policy of favouritism, they argue, has worsened the balkanization of Turkey's émigré community in recent years. Accordingly, organizations like the Federation of Kurdish Associations in Germany (YEK-KOM), the Ahmet Kaya Kurdish Culture Association, and the Kurdish Institute of Paris have undertaken protest action against Erdoğan and his policies (Gazete Sol, 2012; Morin, 2013; Deutsche Welle, 2018b, 2018c, 2018d).

Turkish diplomats and various diaspora organizations cut their relations with Gülenists as soon as the rupture broke out between the AKP and the Gülen Movement in 2013 (Balcı, 2018). After the post-coup purge, Gülenaffiliated individuals and organizations have become the AKP's primary target. Many Gülenists have sought asylum in Europe, an ongoing source of tension between Turkey and several European countries. For example, in 2017, Germany investigated several Turks, including some Diyanet imams, on suspicion of spying on Gülen followers in Germany. The issue came up in the 2017 elections when the Social Democratic Party candidate Martin Schulz argued that Turkey's EU candidacy should be terminated because of the espionage scandal (Bruce, 2019). The investigation was closed without any charges due to a lack of sufficient evidence and several investigated imams escaping from the country (Reuters, 2017; Bruce, 2019). Yet, in 2018, the German domestic intelligence agency, the Federal Office for the Protection of the Constitution, decided to continue to scrutinize the activities of the DiTiB (Daily Sabah, 2020). Ankara has also urged European policymakers to shutter Gülen-linked institutions and schools, and to extradite Gülenists to Turkey. Consequently, three out of 30 Gülenist schools and half of their 170 study centres in Germany have closed (Deutsche Welle, 2018a). Gülen representatives in Europe have condemned Ankara's diaspora engagement as manipulative, criticizing Erdoğan for using overseas Turks to advance partisan interests (Deutsche Welle, 2018b).

Turkey's diaspora rallies have also become a source of suspicion and frustration in Europe, particularly following the 2017 Turkish constitutional referendum that replaced Turkey's parliamentary system with presidentialism, thereby increasing Erdoğan's sphere of influence over the legislative and judicial branches. In March 2017, the Netherlands prohibited Turkey's Minister of Foreign Affairs from visiting the country to address Turkish voters, citing the planned rally's risks to public order and security (Washington Post, 2017). German and Austrian authorities also prevented several pro-Turkish government activities and diaspora rallies as they saw them as an intervention in their domestic affairs (Arkilic, 2018). 


\section{Conclusion}

The recent surge in collective political action among conservative Turkish immigrant organizations in France and Germany reflects the conscious efforts of Turkish policy-makers to empower these organizations in the post-2003 era. Turkey has differentiated its diaspora policies based on the loyalty of organizations within the broader diaspora. An ideologically proximate and loyal diaspora group would be visible and assertive in terms of political action, and therefore, would serve the political interests of the homeland more effectively. Accordingly, the Turkish government has favoured conservative-nationalist and Sunni Islamic immigrant organizations over others. Turkey's new diaspora policies have bolstered conservative diaspora leaders' self-confidence and collective identity, and have enhanced their organizational capacity against backdrop of the rise of Islamophobia in Europe. However, they have also caused frustration in some European host states and generated resentment among other diaspora groups, deepening fragmentation in transnational spaces.

Little is known about the effects of home states' diaspora engagement policies on diaspora communities, particularly in the MENA region. Many researchers in this field have developed a state-centred approach, which has deterred them from conducting interviews with individuals in the diaspora community. This study signals that there is a need for extensive multi-sited fieldwork that focuses on members of the diaspora.

My findings are relevant to the broader literature. Future studies should apply the argument developed in this study to other MENA cases to understand how different diaspora groups perceive and are affected by home states' multi-tiered diaspora policies and whether such differential treatment causes parallel tensions. Similar to Turkey's deliberate selective empowerment of diaspora actors, Maghreb countries have empowered specific pro-regime individuals for security purposes (Brand, 2006, 2018). Egypt's multi-tiered policy has prioritized certain diaspora groups over others for economic and foreign policy purposes (Tsourapas, 2015) and Israel's policy-making has targeted diaspora youth (Abramson, 2017). In recent years, the Moroccan government has also strived to empower certain Moroccan expatriate organizations to deepen Moroccan immigrants' allegiance to their homeland, and to consolidate the political regime in Morocco (Bilgili \& Weyel, 2016).

In light of Glick-Schiller's (2013) 'ethnic association fetish' caveat, future studies could also analyse the impact of diaspora engagement on ordinary organization members or individuals that are not members of any diaspora organization. After all, immigrant organization leaders' views do not necessarily overlap with those of the wider membership and not every member of the diaspora community joins an organization. Research is thus needed on 
the extent to which - and how - empowerment at the leadership and organizational level filters down. Another interesting avenue for future research would be to further examine whether declining homeland support leads to an environment where less-favoured diaspora organizations would be more prone to de-transnationalize, as Laurence (2012) put it.

\section{Notes}

1. This article focuses on the civic or informal dimension of political mobilization, which concerns repertoires of political action outside traditional political channels, such as demonstrations, press releases, and signature campaigns. The term is used interchangeably with other terms, including collective political action and politicization.

2. Fethullah Gülen is a US-based Muslim cleric and the leader of a transnational, ostensibly faith-based education-dialogue movement. He and his followers are accused of plotting the 2016 failed coup attempt in Turkey and are labelled as terrorist by the Turkish government.

3. The UID's previous name was the Union of European Turkish Democrats (UETD). The organization changed its name after Germany's Federal Office for the Protection of the Constitution announced in 2018 that the UETD was incompatible with Germany's constitutional order and that through the UETD the Turkish government collected large amounts of information on Turkish opposition groups based in Germany.

4. Interview, YTB official, Ankara, 25 June 2019.

5. Interview, FUAF official, Paris, 18 January 2019.

6. Interview, YTB official, Ankara, 24 July 2013.

7. Interview, Turkish Consulate official, Strasbourg, 28 May 2013.

8. Interview, Turkish Consulate official, Paris, 28 January 2019.

9. Interview, DітіB official, Strasbourg, 28 May 2013.

10. Interview, Turkish Consulate official, Paris, 28 January 2019.

11. Interview, Turkish Federation official, Paris, 25 February 2013.

12. Interview, COJEP official, Strasbourg, 16 March 2013.

13. Interview, Turkish Consulate official, Paris, 28 January 2019.

14. Interview, Turkish Federation official, Paris, 17 January 2019.

15. Interview, Turkish Federation official, Paris, 17 January 2019.

16. Interview, DiTiB official, Paris, 14 May 2013.

17. Interview, DiтiB official, Strasbourg, 28 May 2013.

18. Interview, DiTiB official, Strasbourg, 28 May 2013.

19. Interview, Millî Görüş official, Paris, 17 May 2013.

20. Interview, Millî Görüş official, Paris, 19 March 2013.

21. Interview, Millî Görüş official, Paris, 15 January 2019.

22. Interview, Union of Islamic Cultural Centres official, Paris, 28 January 2019.

23. Interview, Turkish Embassy official, Berlin, 7 November 2003.

24. interview, Turkish Consulate official, Berlin, 3 December 2013.

25. Interview, Diyanet official, Ankara, 24 July 2013.

26. Interview, DiтiB official, Cologne, 27 November 2013.

27. Interview, DітіB official, Berlin, 28 October 2013.

28. Interview, DiтiB official, Berlin, 9 October 2013.

29. Interview, Millî Görüş official, Berlin, 10 September 2013. 
30. Interview, Millî Görüş official, Cologne, 19 November 2013.

31. Interview, Millî Görüş official, Berlin, 27 February 2019.

32. Interview, Union of Islamic Cultural Centres official, Berlin, 30 October 2013.

33. Interview, Union of Islamic Cultural Centres official, Cologne, 27 November 2013.

34. Interview, FUAF official, Paris, 16 January 2019.

35. Interview, Paris Alevi Cultural Centre official, Paris, 9 December 2013.

36. Interview, FUAF official, Paris, 16 January 2019.

37. Interview, AABF official, Berlin, 25 February 2019.

38. Interview, AABF official, Cologne, 26 November 2013.

39. Interview, ACORT official, Paris, 22 January 2019.

40. Interview, ACORT official, Paris, 12 December 2013.

41. Interview, TGD official, Berlin, 12 February 2019.

42. Interview, TGD official, Berlin, 29 October 2013.

\section{Acknowledgments}

An earlier version of this article was presented at Otago University's Diasporas, Transnationalism, and Identities Spring Lecture Series, September 30, 2019, Dunedin, New Zealand; the Alexander von Humboldt Foundation's Global Research in the 21st Century: Perspectives of the U.S. Humboldt Network Colloquium, March 2-4, 2017, Washington D.C., USA; and the American Political Science Association Conference, September 1-4, 2016, Philadelphia, USA. The author is grateful for valuable comments received from Gary Freeman, Terri Givens, Sultan Tepe, Ruud Koopmans, Louise Davidson-Schmich, Rolle Alho, Xavier Marquez, Fiona Barker, Kate McMillan, Martin Holland, James Headley, Matt Buehler, and the two anonymous reviewers.

\section{Disclosure statement}

No potential conflict of interest was reported by the author.

\section{Funding}

This work was supported by Victoria University of Wellington under Grant Number [219048] and Grant Number [217910]; the New Zealand European Union Centres Network under Grant Number [E6783]; the University of Texas at Austin [Macdonald Research Fellowship]; and the [Chateaubriand Fellowship] of the French Ministry of Foreign Affairs.

\section{ORCID}

Ayca Arkilic (D) http://orcid.org/0000-0002-1775-3311

\section{References}

Abramson, Y. (2017). Making a homeland, constructing a diaspora: The case of TaglitBirthright Israel. Political Geography, 58, 14-23. https://doi.org/10.1016/j.polgeo. 2017.01.002 
Adamson, F. (2019). Sending states and the making of intra-diasporic politics: Turkey and its diaspora(s). International Migration Review, 53(1), 210-236. https://doi.org/ 10.1177/0197918318767665

Anadolu, Ajansı. (2018). Steinmeier Müslüman Dernek Temsilcilerini Kabul Etti [Steinmeier Welcomed Representatives of Muslim Organizations], January 25. http://aa.com.tr/tr/ dunya/steinmeier-musluman-dernek-temsilcilerini-kabul-etti-/1042589

Akgönül, S. (2005). Religions de Turquie, Religions des Turcs: Nouveaux Acteurs dans l'Europe Élargie [Religions of Turkey, Religions of Turks: New Actors in an Enlarged Europe]. L'Harmattan.

Akgönül, S. (2019). Turkish Islam in Europe: Political Activism and Internal Conflicts, Oasis International Foundation. https://www.oasiscenter.eu/en/turkish-islam-in-europe-akpvs-gulen

Aksel, D. (2019). Home states and homeland politics: Interactions between the Turkish state and its emigrants in France and the United States. Routledge.

Arkilic, A. (2015). The Limits of European Islam: Turkish Islamic Umbrella Organizations and Their Relations with Host Countries-France and Germany. Journal of Muslim Minority Affairs, 35(1), 17-43. https://doi.org/10.1080/13602004.2015.1019193

Arkilic, A. (2016). Between the homeland and host states: Turkey's diaspora policies and immigrant political participation in France and Germany, PhD Dissertation, University of Texas at Austin.

Arkilic, A. (2018). How Turkey's outreach to its diaspora is inflaming tensions with Europe, Monkey Cage, March 26. https://www.washingtonpost.com/news/monkeycage/wp/2018/03/26/how-turkeys-outreach-to-its-diaspora-is-inflaming-tensionswith-europe/

Arkilic, A. (Forthcoming). Turkish populist nationalism in transnational space: Explaining diaspora voting behavior in homeland elections. Journal of Balkan and Near Eastern Studies.

Arkilic, A., \& Gurcan, A. E. (2020). The political participation of Alevis: A comparative analysis of the Turkish Alevi Opening and the German Islam Conference. Nationalities Papers, 1-18. https://doi.org/10.1017/nps.2020.49

Artı33. (2018). Fransa'da Türk dernekleri ortak bildiri hazırladı, o senatöre sert tepki gösterdi [Turkish organizations in France issue joint statement announcing their reaction to Senator], March 3. https://www.arti33.com/fransada-turk-dernekleriortak-bildiri-hazirladi-o-senatore-sert-tepki-gosterdi/

Aydın, Y. (2014). The New Turkish Diaspora Policy, Stiftung Wissenschaft und Politik. https://www.swp-berlin.org/fileadmin/contents/products/research_papers/2014_ 865Q20RP10_adn.pdf

Aydın-Düzgit, S., \& Kaliber, A. (2016). Encounters with Europe in an era of domestic and international turmoil: Is Turkey a de-Europeanising candidate country? South European Society \& Politics, 21(1), 1-14. https://doi.org/10.1080/13608746.2016. 1155282

Balcı, B. (2018). Situating the Gülen movement in France and in Europe. Politics, Religion, and Ideology, 19(1), 69-80. https://doi.org/10.1080/21567689.2018. 1453262

BBC. (2015). Armenian Killings Were Genocide-German President, April 23. http:// www.bbc.com/news/world-europe-32437633

Bevelander, P., \& Veenman, J. (2006). Naturalisation and socioeconomic integration: The case of the Netherlands, IZA Discussion Paper No. 2153. http://repec.iza.org/ dp2153.pdf 
Bilgili, Ö., \& Weyel, S. (2016). Diaspora engagement policies of countries with similar emigration histories: Morocco and Turkey. In D. Beshavor \& M. Lopez (Eds.), Adjusting to a world in motion: Trends in global migration and migration policy (pp. 390-413). Oxford University Press.

Brand, L. (2006). Citizens Abroad: State and Emigration in the Middle East and North Africa. Cambridge University Press.

Brand, L. (2018). Expatriates and home state development. Mashriq \& Mahjar, 5(1), 11-35. https://doi.org/10.24847/55i2018.158

Bruce, B. (2019). Governing Islam Abroad: Turkish and Moroccan Muslims in Western Europe. Palgrave McMillan.

Castles, S., \& Kosack, G. (1973). Immigrant workers and class structure in Western Europe. Oxford University Press.

Cinalli, M., \& Giugni, M. (2013). Political opportunities, citizenship models and political claim-making over Islam. Ethnicities, 13(2), 147-164. https://doi.org/10.1177/ 1468796812470896

CNN Türk. (2010). Fransa'daki Türklere Anayasa Degişikliğini Anlattı [PM Explains Constitutional Reform to Turks in France], April 7. http://www.cnnturk.com/2010/ dunya/04/07/fransadaki.turklere.anayasa.degisikligini.anlatti/571245.0/

Daily Sabah. (2020). DITIB launches education program to train imams in Germany, January 10. https://www.dailysabah.com/politics/2020/01/10/ditib-launcheseducation-program-to-train-imams-in-germany

Der Spiegel. (2008). Cologne's Turkish Spectacle: Erdogan's One-Man Show, February 11. http://www.spiegel.de/international/germany/cologne-s-turkish-spectacleerdogan-s-one-man-show-a-534519.html

Der Spiegel. (2011). Erdogan Urges Turks Not to Assimilate, February 28. http://www. spiegel.de/international/europe/erdogan-urges-turks-not-to-assimilate-you-arepart-of-germany-but-also-part-of-our-great-turkey-a-748070.html

Deutsche Welle. (2008). Erdoğan'ın Köln Çıkarması [Erdoğan's Cologne Landing], February 11. http://www.dw.com/tr/erdo\%C4\%9Fan\%C4\%B1n-k\%C3\%B6ln-\%C3\% A7\%C4\%B1 karmas\%C4\%B1/a-3119307

Deutsche Welle. (2018a). Gülencilerin yeni merkezi: Almanya [The New Gülenist Centre: Germany], July 13. https://www.dw.com/cda/tr/gülencilerin-yeni-merkezialmanya/a-44650646

Deutsche Welle. (2018b). Erdoğan'ın Ziyareti ve Almanya'daki Türkler [Erdoğan's Visit and Turks in Germany], August 1. https://www.dw.com/tr/erdoğanın-ziyareti-vealmanyadaki-türkler/a-44908071

Deutsche Welle. (2018c). Almanya'daki Kürtlerden Erdoğan'i protesto hazırlığı [German Kurds are Preparing to Protest Erdoğan], August 3. https://www.dw.com/ tr/almanyadaki-kürtlerden-erdoğanı-protesto-hazırlığı/a-44950772

Deutsche Welle. (2018d). Fransa'da Erdoğan'a 11 Kasım Protestosu $[11$ November Protest in France against Erdoğan], November 7. https://www.dw.com/tr/fransadaerdo\%C4\%9Fana-11-kas\%C4\%B1m-protestosu/a-46197802

Esen, B., \& Gumuscu, S. (2015). Rising competitive authoritarianism in Turkey. Third World Quarterly, 37(9), 1581-1606. https://doi.org/10.1080/01436597.2015. 1135732

Fargues, P. (2013). International migration and the nation state in Arab countries. Middle East Law and Governance, 5(1-2), 5-35. https://doi.org/10.1163/1876337500501001 
Fennema, M., \& Tillie, J. (1999). Political participation and political trust in Amsterdam. Civic communities and ethnic networks. Journal of Ethnic and Migration Studies, 25(4), 703-726. https://doi.org/10.1080/1369183X.1999.9976711

Gamlen, A. (2018). Why engage diasporas? In R. Cohen \& C. Fischer (Eds.), Routledge Handbook of Diaspora Studies (pp. 302-310). Routledge.

Ganz, M. (2000). Resources and resourcefulness: Strategic capacity in the unionization of California Agriculture, 1959-1966. American Journal of Sociology, 105(4), 1003-1062. https://doi.org/10.1086/210398

Gazete Sol. (2012). Alevi örgütlerinden Erdoğan protestosu [Erdoğan protest from Alevi organizations], October 31. https://editor.sol.org.tr/soldakiler/alevi-orgutlerindenerdogan-protestosu-ortadogu-diktatorunu-almanyada-istemiyoruz-haberi

Glick-Schiller, N. (2013). The transnational migration and paradigm. In D. Halm \& Z. Sezgin (Eds.), Migration and organized civil society: Rethinking national policy (pp. 25-43). Routledge.

Goodwin, J. (2001). No other way out: States and revolutionary movements, 1945-1991. Cambridge University Press.

Gsir, S. (2014). Civic participation and integration: A country of origin perspective, European University Institute Migration Policy Centre INTERACT Research Report 3. http://cadmus.eui.eu/bitstream/handle/1814/31244/INTERACT-RR-2014_03.pdf? sequence $=1$

Hürriyet. (2012a). Türkçe Için 2.541 Imza [2,541 Signatures for Turkish Language], August 26. http://avrupa.hurriyet.com.tr/haberler/gundem/1273655/turkceicinimza

Hürriyet. (2012b). Çifte Vatandaşıık Için Imza Kampanyası Hızlandı [Dual Citizenship Signature Campaign Accelerates], December 19. http://avrupa.hurriyet.com.tr/ haberler/gundem/1347501/cifte-vatandaslik-icin-sonbin-imza

Hürriyet. (2014a). Irkçıya Karşı Haydi Sokağa! [To the Streets against Racists!], January 4. http://www.hurriyet.com.tr/irkciya-karsi-haydi-sokaga-27883649

Hürriyet. (2014b). Yerel Seçimlerde 130 Türk Aday Var [There are 130 Turkish Candidates in Local Elections], March 22. http://www.hurriyet.com.tr/yerel-secimlerde-130-turk -aday-var-26061465

Hürriyet. (2014c). "Başbakan Erdoğan Fransa'daki Türklere Seslendi [Prime Minister Erdoğan Addressed Turks in France], June 21. http://www.hurriyet.com.tr/basba kan-erdogan-fransadaki-turklere-seslendi-26657828

Hürriyet. (2014d). DiтiB'den Kampanya: Müslüman Cemaat Kütügü̈ [DітіB Campaign: Muslim Community Registry], December 16. http://www.hurriyet.com.tr/ditib-tenkampanya-musluman-cemaat-kutugu-27782385

Hürriyet. (2015). Almanya'da Soykırım Iddialarına Karşı Yürüyüş [March in Germany against Genocide Allegations], April 22. http://www.hurriyet.com.tr/avrupa/alma nyada-soykirim-iddialarina-karsi-yuruyus- 28797560

Ireland, P. (1994). The policy challenge of ethnic diversity. Harvard University Press.

Iskander, N. (2010). Creative state: Forty years of migration and development policy in Morocco and Mexico. Cornell University Press.

Kaya, A. (2019). Turkish-origin migrants and their descendants: Hyphenated identities in transnational space. Palgrave Macmillan.

Koopmans, R., Statham, P., Giugny, M., \& Passy, F. (2005). Contested citizenship: Immigration and cultural diversity in Europe. University of Minnesota Press.

Laurence, J. (2012). The Emancipation of Europe's Muslims: The state's role in minority integration. Princeton University Press. 
Maxwell, R. (2012). Ethnic minority migrants in Britain and France: Integration trade-offs. Cambridge University Press.

McClain, P., Carew, J. J., Walton, E., \& Watts, C. (2009). Group membership, group identity, and group consciousness: Measures of racial identity in American politics. Annual Review of Political Science, 12(1), 471-485. https://doi.org/10.1146/annurev. polisci.10.072805.102452

Le Monde. (2012). Le Parlement adopte la loi sur le génocide arménien [Parliament adopts Armenian Genocide Act], January 23. http://www.lemonde.fr/europe/arti cle/2012/01/23/lle-parlement-adopte-la-loi-sur-le-genocide-armenien_1633536_ 3214.html

Morales, L., \& Morariu, M. (2011). Is 'Home' a distraction? The role of migrants' transnational practices in their political integration into receiving-country politics. In L. Morales \& M. Giygny (Eds.), Social capital, political participation and migration in Europe (pp. 140-171). Palgrave.

Morin, A. C. (2013). Paris'ten Taksim'e Destek [Support from Paris to Taksim], ACORT, June 6. http://acort.org/?p=355

Moss, D. (2016). Transnational repression, diaspora mobilization, and the case of the Arab spring. Social Problems, 63(4), 480-498. https://doi.org/10.1093/socpro/ spw019

Mügge, L. (2012). Managing transnationalism: Continuity and change in Turkish state policy. International Migration, 50(1), 20-38. https://doi.org/10.1111/j.1468-2435. 2010.00666.x

Ögelman, N. (2000). Directing discontent: Turkish-origin associations in Germany, PhD. Dissertation, University of Texas at Austin.

Ögelman, N. (2003). Documenting and explaining the persistence of homeland politics among Germany's Turks. International Migration Review, 37(1), 163-193. https://doi. org/10.1111/j.1747-7379.2003.tb00133.x

Öktem, K. (2014). Turkey's New Diaspora Policy: The Challenge of Inclusivity, Outreach, and Capacity, Istanbul Policy Centre. http://ipc.sabanciuniv.edu/wp-content /uploads/2014/08/14627_Kerem\%C3\%96ktenWEB.18.08.pdf

Okyay, A. (2015). Diaspora-making as a state-led project, PhD Dissertation, European University Institute.

Østergaard-Nielsen, E. (2003a). Turkey and the 'Euro-Turks': Overseas nationals as an ambiguous asset. In E. Østergaard-Nielsen (Ed.), International migration and sending countries: Perceptions, policies and transnational relations (pp. 77-99). Palgrave Macmillan.

Østergaard-Nielsen, E. (2003b). Transnational politics: Turks and Kurds in Germany. Routledge.

Pearlman, W. (2018). Competing for Lebanon's diaspora: Transnationalism and domestic struggles in a weak state. International Migration Review, 48(1), 34-75. https://doi. org/10.1111/imre.12070

Pitt, B. (2014). German-Turkish NGOs Condemn Growing Islamophobia in Germany, Islamophobia Watch, December 30. http://www.islamophobiawatch.co.uk/germanturkish-ngos-condemn-growing-islamophobia-in-germany/

Reuters. (2017). Germany drops inquiry against Turkish imams suspected of spying on Erdogan's behalf, December 7. https://www.reuters.com/article/uk-germany-tur key-spying/germany-drops-inquiry-against-turkish-imams-suspected-of-spying-onerdogans-behalf-idUKKBN1E023C

Rosenow-Williams, K. (2012). Organizing Muslims and integrating Islam. New developments in the 21st century. Brill. 
Sabah. (2016). Almanya'daki Türklerden Büyük Protesto [Massive Protest from Turks in Germany], June 2. https://www.sabah.com.tr/dunya/2016/06/02/almanyadakiturklerden-buyuk-protesto

Sabah. (2018). Fransa'daki Türklerden Fransız belediyesine 'FETÖ' tepkisi [FETÖ Reaction to French Municipality from Turks in France], March 25. https://www.sabah.com.tr/ dunya/2018/03/26/fransadaki-turklerden-fransiz-belediyesine-feto-tepkis

Şahin-Mencütek, Z., \& Baser, B. (2018). Mobilizing diasporas: Insights from Turkey's attempts to reach Turkish citizens abroad. Journal of Balkan and Near Eastern Studies, 20(1), 86-105. https://doi.org/10.1080/19448953.2017.1375269

Schiffauer, W. (2010). Nach dem Islamismus - Eine Ethnografie der Islamischen Gemeinschaft Milli Görüs [After Islamism - An Ethnography of the Islamic Community Milli Görüs]. Suhrkamp Verlag.

Schönwalder, K. (2013). Immigrant representation in Germany's regional states: The puzzle of uneven dynamics. West European Politics, 36(3), 634-651. https://doi.org/ $10.1080 / 01402382.2013 .773730$

Schrover, M., \& Vermeulen, F. (2005). Immigrant organisations. Journal of Ethnic and Migration Studies, 31(5), 823-832. https://doi.org/10.1080/13691830500177792

Şenay, B. (2013). Beyond Turkey's borders: Long-distance Kemalism, state politics and the Turkish diaspora. I. B. Tauris.

Sökefeld, M. (2008). Struggling for recognition: The Alevi movement in Germany and in transnational space. Berghahn Books.

Strijbis, O. (2015). Beyond opportunity structures: Explaining migrant protest in Western Europe, 1975-2005. Comparative Migration Studies, 3(5), 1-22. https://doi. org/10.1007/s40878-015-0005-8

Taş, H. (2017). A history of Turkey's AKP-Gülen conflict. Mediterranean Politics, 23(3), 395-402. https://doi.org/10.1080/13629395.2017.1328766

Tsourapas, G. (2015). Why do states develop multi-tiered emigration policies? Evidence from Egypt. Journal of Ethnic and Migration Studies, 42(13), 2192-2214. https://doi.org/10.1080/1369183X.2015.1049940

Tsourapas, G. (2018a). The politics of migration in modern Egypt: Strategies for regime survival in autocracies. Cambridge University Press.

Tsourapas, G. (2018b). Authoritarian emigration states: Soft power and cross-border mobility in the Middle East. International Political Science Review, 39(3), 400-416. https://doi.org/10.1177/0192512118759902

Tsourapas, G. (2018c). Theorizing state-diaspora relations in the Middle East: Authoritarian emigration states in comparative perspective. Mediterranean Politics, 25(2), 135-159. https://doi.org/10.1080/13629395.2018.1511299

Turkish Ministry of Foreign Affairs. (2020a). Turkish citizens living abroad. http://www. mfa.gov.tr/the-expatriate-turkish-citizens.en.mfa

Turkish Ministry of Foreign Affairs. (2020b). Relations between Turkey and France. http://www.mfa.gov.tr/relations-between-turkey-and-france.en.mfa

Turkish Ministry of Foreign Affairs. (2020c). Relations between Turkey and the Federal Republic of Germany. http://www.mfa.gov.tr/relations-between-turkey-and-thefederal-republic-of-germany.en.mfa

Ünver, C. (2013). Changing diaspora politics of Turkey and public diplomacy. Turkish Policy Quarterly, 12(1), 181-189.http://turkishpolicy.com/Files/ArticlePDF/changingdiaspora-politics-of-turkey-and-public-diplomacy-spring-2013-en.pdf

Varadarajan, V. (2010). The Domestic Abroad: Diasporas in International Relations. Oxford University Press. 
Vermeulen, F. (2018). The Paradox of immigrant political participation in Europe amidst crises of multiculturalism. In C. Menjívar, M. Ruiz, \& I. Ness (Eds.), The Oxford Handbook of Migration Crises. (pp. 801-817). Oxford University Press. https://doi.org/10.1093/ oxfordhb/9780190856908.013.26

Washington Post. (2017). Netherlands cancels Turkish foreign minister's visit in spiraling feud between Europe and Turkey, March 11. https://www.washingtonpost.com/ world/netherlands-cancels-visit-by-turkish-foreign-minister-in-spiraling-feudbetween-europe-and-turkey/2017/03/11/acc2c8ba-0655-11e7-a391-651727e77fc0_ story.html

Yalaz, E. (2014). Immigrant political incorporation: Institutions, groups, and inter-ethnic context, PhD Dissertation, Rutgers University.

Yanaşmayan, Z., \& Kaşlı, Z. (2019). Reading diasporic engagements through the lens of citienship: Turkey as a test case. Political Geography, 70, 24-33. https://doi.org/10. 1016/j.polgeo.2019.01.004

YTB. (2015a). France Activity Report. https://ytb.gov.tr/ytbadmin/assets/uploads/files/ FRANSA.pdf

YTB. (2015b). Germany Activity Report. https://ytb.gov.tr/ytbadmin/assets/uploads/ files/ALMANYA.pdf

YTB. (2016). Administrative Activity Report. https://www.ytb.gov.tr/uploads/resimler/ activity_reports/2016-idare-faaliyet-raporu.pdf

YTB. (2020). Sivil Toplum Destekleri [Support for Civil Society]. https://www.ytb.gov.tr/ destekler-ve-burslar/sivil-toplum-destekleri 